\title{
Phytochemical Screening and Cytotoxic Effects of Crude Extracts of Pereskia Bleo Leaves
}

Siti Farhanah Mohd-Salleh, Norzila Ismail, Wan Suriyani Wan-Ibrahim \& Tuan Nadrah Naim Tuan Ismail

To cite this article: Siti Farhanah Mohd-Salleh, Norzila Ismail, Wan Suriyani Wan-Ibrahim \& Tuan Nadrah Naim Tuan Ismail (2020): Phytochemical Screening and Cytotoxic Effects of Crude Extracts of Pereskia Bleo Leaves, Journal of Herbs, Spices \& Medicinal Plants, DOI: $10.1080 / 10496475.2020 .1729287$

To link to this article: https://doi.org/10.1080/10496475.2020.1729287

曲 Published online: 18 Feb 2020.

Submit your article to this journal ๘

山 Article views: 21

Q View related articles $\sqsubset$

View Crossmark data $־$ 


\title{
Phytochemical Screening and Cytotoxic Effects of Crude Extracts of Pereskia Bleo Leaves
}

\author{
Siti Farhanah Mohd-Salleh (10 ${ }^{a}$, Norzila Ismaila, Wan Suriyani Wan-Ibrahimª, \\ and Tuan Nadrah Naim Tuan Ismail ${ }^{\mathrm{b}}$ \\ aDepartment of Pharmacology, School of Medical Sciences, Universiti Sains Malaysia, Kubang Kerian,

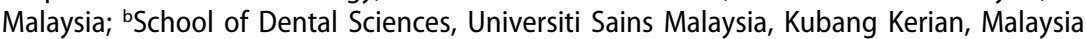

\begin{abstract}
The phytocompounds in crude solvent extracts of Pereskia bleo leaves were identified and their cytotoxic effects on cancer cell lines were determined. Crude extracts were obtained via maceration and subjected to GCMS analysis. Then, each extract was incubated with HeLa, MDA-MB-231, SW480, and NIH/3T3 cell lines for 72 h. 3-(4,5-dimethylthiazol-2-yl)-2,5-diphenyltetrazolium bromide assay was done to determine $\mathrm{IC}_{50}$ values of each extract. Terpenoids, sterols, alkaloids, fatty acids and phenolic compounds were identified from the crude extracts of $P$. bleo leaves. Other compounds identified were $\gamma$-sitosterol, $\beta$-tocopherol, and $\gamma$-tocopherol. The ethyl acetate extract had potent cytotoxic effect against HeLa and MDA-MB-231 cancer cells as noted by the lowest $\mathrm{IC}_{50}$ values
\end{abstract}

\section{ARTICLE HISTORY}

Received 14 October 2019

\section{KEYWORDS}

GCMS; phytocompounds; antiproliferative; anti-cancer; maceration

\section{Introduction}

Cancer, a malignant tumor caused by uncontrolled proliferation of abnormal cells in the body is the second cause of death in the world. ${ }^{[1]}$ Chemotherapy is costly and causes detrimental side effects to the patients due to low selectivity of target cells. ${ }^{[2]}$ Due to the development of drug resistance, chemotherapy has become a less effective treatment option and hence there is a need to find a safer and sustainable treatment for cancer. Today, plants have gained the attention of researchers as a good source of anti-cancer agents ${ }^{[3]}$ as they are easily available, less costly and have insignificant adverse side effects. Pereskia bleo (Cactaceae) locally known as "Jarum tujuh bilah" or "Cak Sing Cam" in Malaysia ${ }^{[4]}$, has been studied for health promoting properties. The leaves of $P$. bleo are effective in traditional cancer treatment when consumed raw or as tea, ${ }^{[5-7]}$ and also used for treating hypertension, diabetes mellitus, rheumatism, inflammation, gastric pain, and ulcer. ${ }^{[5-7]}$

Phytochemical studies on the leaves of $P$. bleo commonly use fractions instead of crude extracts. In traditional medicine, crude extract is preferred 
instead of isolated single compounds because the synergies of all compounds that are present in the plant offers greater effectiveness. ${ }^{[8]}$ A crucial step in the isolation of bioactive compounds from plants is the extraction process. Soxhlet extraction, common practice for plant leaves extraction to demonstrate their cytotoxic effect, ${ }^{[4,9,10]}$ requires heating at high temperature leading to the loss of thermolabile compounds. ${ }^{[11]}$ In contrast, maceration is a simple procedure that involves the soaking of plant materials in the solvent for a minimum of $3 \mathrm{~d}$ with frequent shaking at room temperature. ${ }^{[12]}$ The low extraction temperature in maceration can preserve the phytocompounds from degradation. ${ }^{[13]}$

Gas chromatography mass spectrometry (GCMS) offers rapid analysis with high sensitivity and selectivity, better resolution, high throughput, and broad coverage. ${ }^{[14,15]}$ Previous studies involving GCMS on crude methanol extract of $P$. bleo leaves revealed the presence of $\beta$-sitosterol and stigmasterol though high amount of sugar and fatty acids were found in the aqueous extract. ${ }^{[16]}$ In this study, the maceration extraction technique was adopted to explore the therapeutic potential of $P$. bleo leaves crude extracts. The present research was carried out to identify the phytochemicals present in the crude extracts of $P$. bleo leaves by using hexane, ethyl acetate, methanol, and aqueous via GCMS technique and test the extracts on HeLa, MDA-MB-231, and SW480 cancer cell lines.

\section{Materials and Methods}

\section{Preparation of Plant Extracts}

The leaves of $P$. bleo were collected from Kota Bharu, Kelantan, verified and a voucher specimen (Voucher No: 11575) was deposited at the herbarium in the School of Biology, Universiti Sains Malaysia (USM), Penang. P. bleo leaves were cleaned, oven-dried $\left(50^{\circ} \mathrm{C}\right)$ and powdered. The powder $(10 \mathrm{~g})$ was soaked in $500 \mathrm{~mL}$ of hexane, ethyl acetate and methanol successively for $\sim 30 \mathrm{~d}$. Then, the extracts were filtered (Whitmann paper no. 1) and concentrated by using rotary evaporator. Another $10 \mathrm{~g}$ of the leaf powder was boiled in $450 \mathrm{~mL}$ water $\left(50^{\circ} \mathrm{C}\right)$ until it was reduced to one-third of its initial volume and filtered. Subsequently, the aqueous extract was frozen $\left(-20^{\circ} \mathrm{C}\right)$ overnight and dried using freeze dryer. All the extracts were stored at $-20^{\circ} \mathrm{C}$ until use.

\section{Cancer Cell Lines}

MDA-MB-231 (breast cancer), HeLa (cervical cancer), SW480 (colon cancer), and NIH 3T3 (normal mouse fibroblast) cell lines used in this study were obtained from ATCC. All the cell lines were cultured in Dulbecco's Modified Eagle's Medium (DMEM; Gibco) supplemented with $10 \%$ of fetal 
bovine serum (FBS; Gibco) and 1\% of penicillin-streptomycin (Gibco) under atmospheric humidity $\left(5 \% \mathrm{CO}_{2}\right.$ at $\left.37^{\circ} \mathrm{C}\right)$.

\section{Gas Chromatography Mass Spectrometry (GCMS) Analysis}

The GCMS analysis was carried out by using Hewlett Packard 6890 Gas Chromatograph with $5973 \mathrm{~N}$ Mass Selective Detector. The column was a fused silica capillary, HP-5 column $(30 \mathrm{~m} \times 0.25 \mathrm{~mm}$ i.d. $\times 0.25 \mu \mathrm{m}$ film thickness) (Agilent Technologies, USA). The carrier gas was helium with a flow rate of $1.0 \mathrm{~mL} \mathrm{~min}{ }^{-1}$ with the oven temperature programmed from $50^{\circ} \mathrm{C}(5 \mathrm{~min})$ to $300^{\circ} \mathrm{C}(10 \mathrm{~min})$ at a rate of $25^{\circ} \mathrm{C} \mathrm{min}^{-1}$. Both injection and interface temperatures were set at $280^{\circ} \mathrm{C}$. One $\mu \mathrm{L}$ sample was injected in split-less mode and analyzed in MS full scan mode $(\mathrm{m} / z$ 40-650). The electron ionization was fixed at $70 \mathrm{eV}$. Acquisition of data was performed using Chemsation software. Identification of phytochemical constituents was accomplished based on mass spectral matching with National Institute of Standards and Technology (NIST02) and Wiley 275 libraries ( $\geq 80 \%$ match).

\section{Cytotoxicity Assay}

In vitro cytotoxicity activity of $P$. bleo leaves crude extracts were determined by colorimetric assay of 3-(4,5-dimethylthiazol-2-yl)-2,5-diphenyl-tetrazolium bromide (MTT), which is based on the ability of viable cells to convert soluble MTT (yellow) to insoluble formazan product (dark purple) through mitochondrial enzymatic activity. A total of $100 \mu \mathrm{L}$ cell suspension $\left(5 \times 10^{4}\right.$ cells $)$ was seeded in 96 well microplates for $24 \mathrm{~h}$. The medium was removed from each well and $200 \mu \mathrm{L}$ of complete medium was added. The cells were then treated with $2 \mu \mathrm{L}$ of $P$. bleo leaves extracts that had been dissolved in dimethyl sulfoxide (DMSO) at various concentrations (3-990 $\mu \mathrm{g} \mathrm{mL}^{-1}$ ) and also with tamoxifen (positive control). After $72 \mathrm{~h}$ of incubation period, the medium was pipetted out and gently replaced with $20 \mu \mathrm{L}$ of MTT solution $\left(5 \mathrm{mg} \mathrm{mL}^{-1}\right)$. After $4 \mathrm{~h}$, $200 \mu \mathrm{L}$ of DMSO was added to dissolve the formazan crystal product. Absorbance was recorded at $570 \mathrm{~nm}$ using enzyme-linked immunosorbent assay (ELISA) plate reader. Results were obtained from three independent experiments with triplicate for each experiment. $\mathrm{IC}_{50}$ value (concentration that inhibit $50 \%$ of cell proliferation) was determined as:

$$
\text { Cell viability }(\%)=\frac{\text { Absorbance of treated cells }}{\text { Absorbance of control }} \times 100 \%
$$




\section{Statistical Analysis}

Data were expressed as mean \pm standard deviation (SD) and analyzed by repeated measure one-way ANOVA analysis $(p<0.05)$ using GraphPad PRISM (ver. 7).

\section{Results}

\section{GCMS Analysis of P. bleo Leaves Extracts}

Twenty-four compounds were identified from the hexane extract of P. bleo leaves consisting of terpenoids, sterols, phenolic compounds, fatty acids, and others (Tables 1-4). Sterol was identified at the greatest amount representing $23.25 \%$ of total hexane extract with the main compound $\gamma$-sitosterol. Phenolic compounds consisted of $\beta$-tocopherol and $\gamma$-tocopherol representing $9.32 \%$ from the total amount of the extract (Table 1).

Ethyl acetate extract of $P$. bleo leaves showed the presence of terpenoids, phenols, sterols and fatty acids. Terpenoids were the greatest with $24.75 \%$ from the total ethyl acetate extract of $P$. bleo leaves consisted majority of phytol. New compounds such as loliolide and neophytadiene in addition to $\gamma$-sitosterol were also identified (Table 2).

Phytochemicals identified from the methanol and aqueous extracts of P. bleo leaves included terpenoids, sterols, phenols, alkaloids, and fatty acids. Fatty acids were the highest in both methanol (9.8\%) and aqueous (5.51\%) extracts of $P$. bleo leaves (Tables $3 \& 4$ ).

\section{Cytotoxicity Activity Assay}

The leaf extracts of $P$. bleo were subjected to cytotoxicity assay on selected cancer and normal cell lines via MTT assay. Tamoxifen was used as control positive for this study. The ethyl acetate extract of $P$. bleo leaves exhibited the strongest cytotoxic effect on HeLa cells at $\mathrm{IC}_{50}$ value of $17.51 \pm 8.6 \mu \mathrm{g} \mathrm{mL}^{-1}$ (Table 5). The number of HeLa cells were reduced after $72 \mathrm{~h}$ incubation with ethyl acetate extract. In addition, it was also active toward MDA-MB-231 cells at $19.39 \pm 1.26 \mu \mathrm{g} \mathrm{mL} \mathrm{m}^{-1}$. Meanwhile, in SW480 cells, it exhibited moderate cytotoxic effect with an $\mathrm{IC}_{50}$ value of $31.80 \pm 16.1 \mu \mathrm{g} \mathrm{mL}{ }^{-1}$.

\section{Discussion}

Phytochemical studies on the leaves of $P$. bleo extracted with solvents of different polarity detected terpenoids, sterols, alkaloids, fatty acids, sugars, and phenols. Extraction methods are important in the discovery of phytochemicals from plants because different extraction techniques will isolate different compounds and heating will eliminate heat-sensitive compounds. ${ }^{[1]}$ 


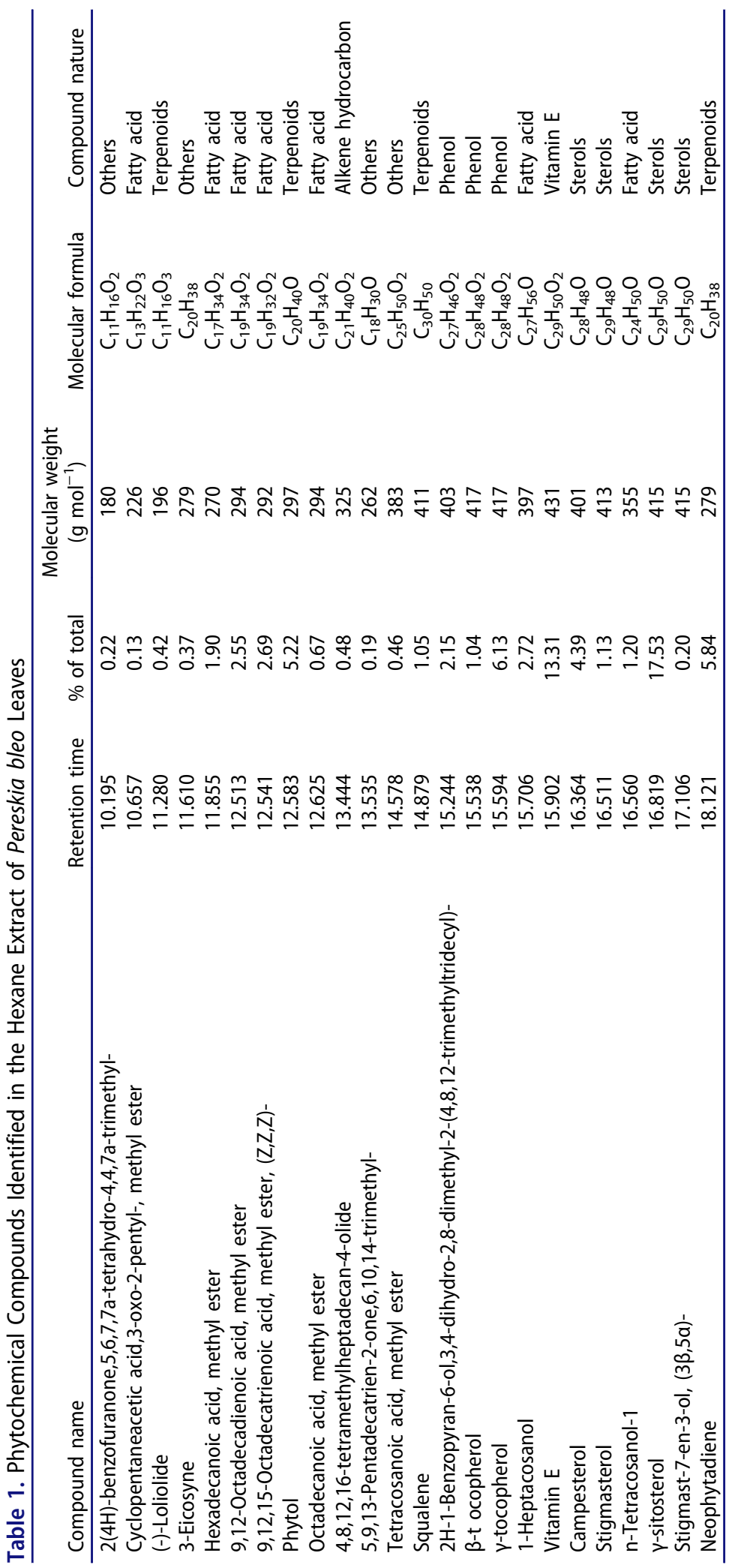




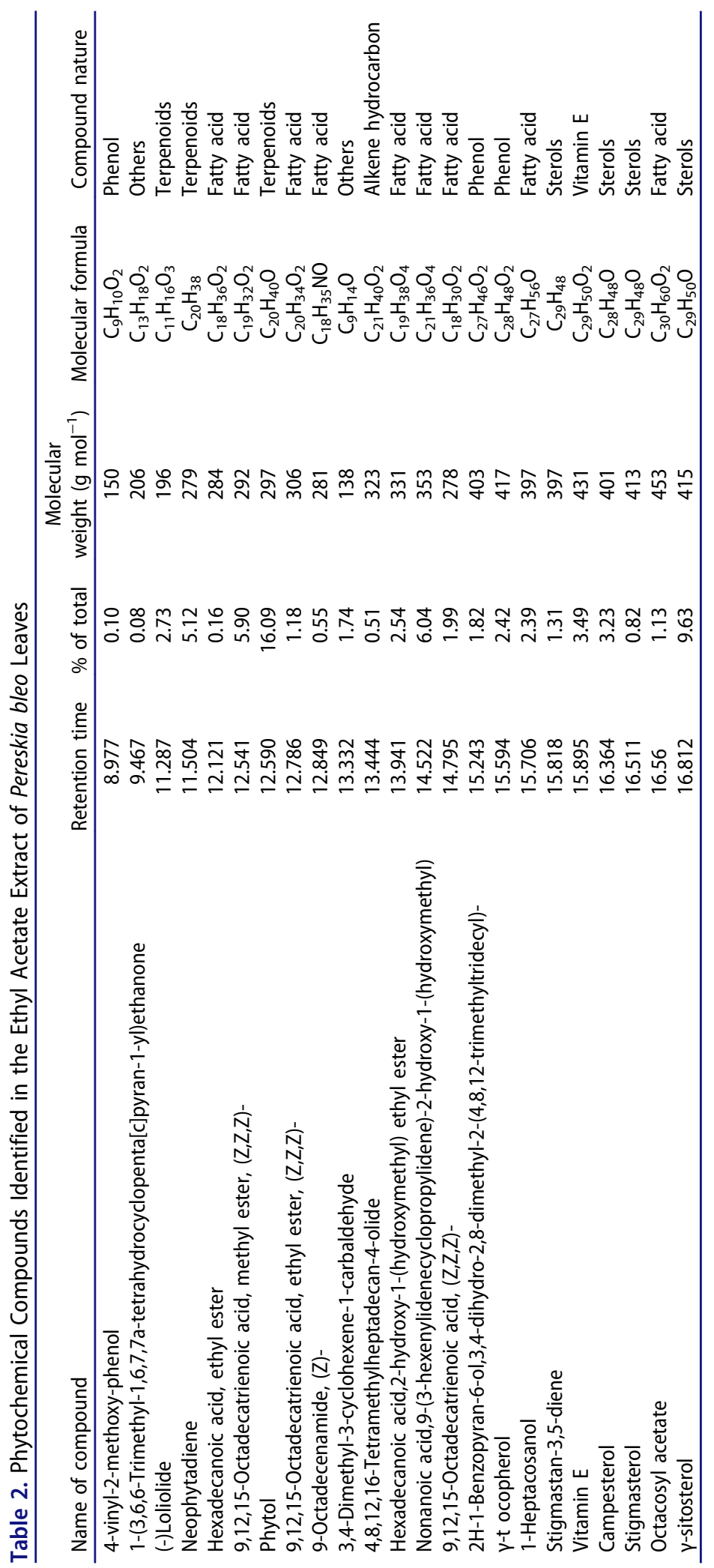




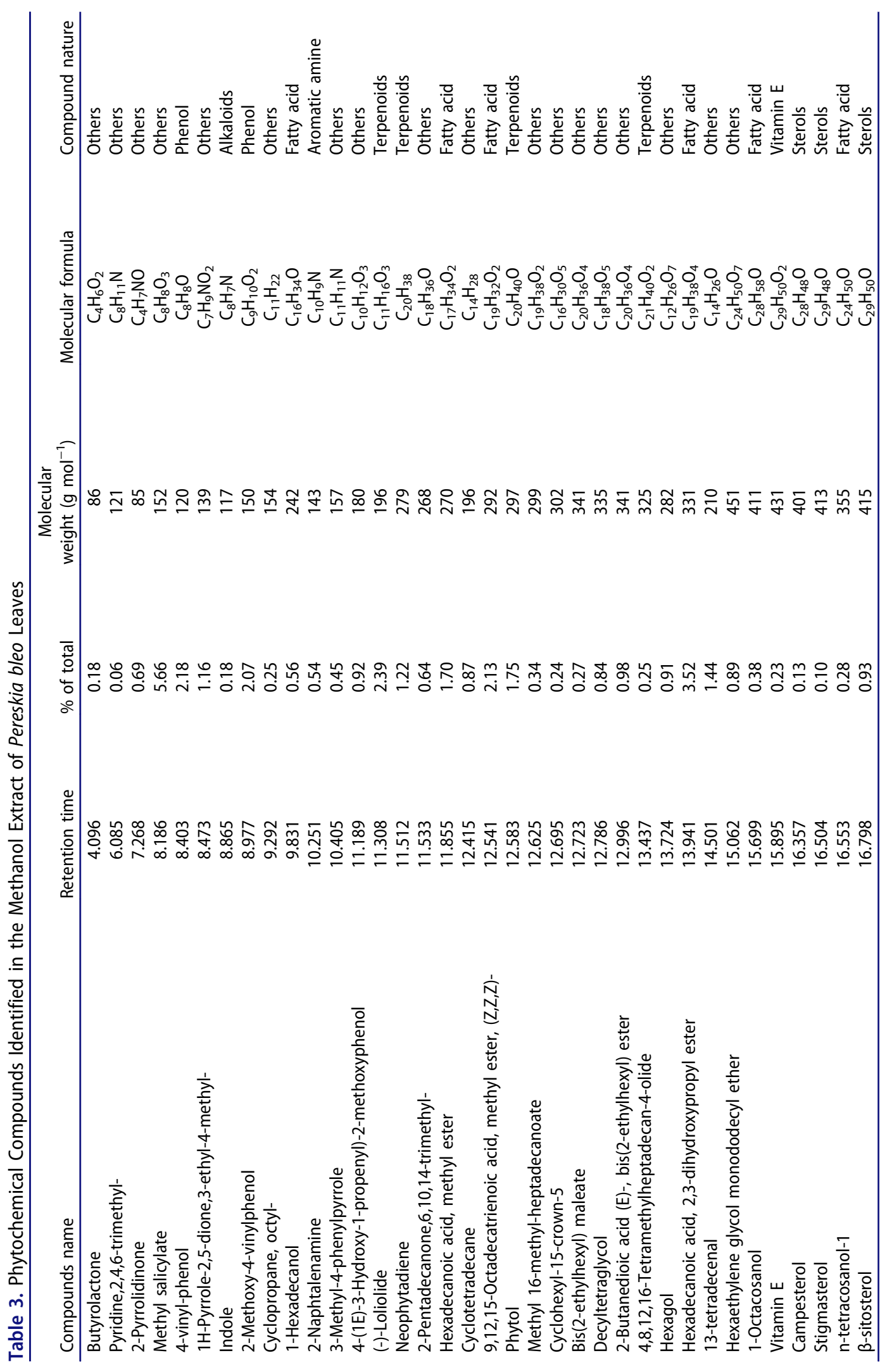


Table 4. Phytochemical Compounds Identified in the Aqueous Extract of Pereskia bleo Leaves

\begin{tabular}{|c|c|c|c|c|c|}
\hline Name of compound & $\begin{array}{l}\text { Retention } \\
\text { time }\end{array}$ & $\begin{array}{l}\% \text { of } \\
\text { total }\end{array}$ & $\begin{array}{l}\text { Molecular } \\
\text { weight }(\mathrm{g} \\
\left.\mathrm{mol}^{-1}\right)\end{array}$ & $\begin{array}{l}\text { Molecular } \\
\text { formula }\end{array}$ & $\begin{array}{c}\text { Compound } \\
\text { nature }\end{array}$ \\
\hline Pyrazine, trimethyl- & 6.218 & 0.34 & 122 & $\mathrm{C}_{7} \mathrm{H}_{10} \mathrm{~N}_{2}$ & Others \\
\hline Thiazolidine,2-isobutyl- & 8.067 & 1.90 & 145 & $\mathrm{C}_{7} \mathrm{H}_{15} \mathrm{NS}$ & Others \\
\hline Benzofuran,2,3-dihydro- & 8.389 & 0.82 & 120 & $\mathrm{C}_{8} \mathrm{H}_{8} \mathrm{O}$ & Others \\
\hline 2-Methoxy-4-vinylphenol & 8.977 & 1.96 & 150 & $\mathrm{C}_{9} \mathrm{H}_{10} \mathrm{O}_{2}$ & Phenol \\
\hline 4-methyl-2,5-dimethoxybenzaldehyde & 10.314 & 0.76 & 198 & $\mathrm{C}_{10} \mathrm{H}_{12} \mathrm{O}_{3}$ & Others \\
\hline 1,2,3,4-Tetrahydro-cyclopenta(b)indole & 10.405 & 1.80 & 157 & $\mathrm{C}_{11} \mathrm{H}_{11} \mathrm{~N}$ & Alkaloids \\
\hline Methyl dihydrojasmonate & 10.65 & 2.30 & 226 & $\mathrm{C}_{13} \mathrm{H}_{22} \mathrm{O}_{3}$ & Fatty acid \\
\hline Octanal, 2-(phenylmethylene)- & 11.162 & 1.28 & 216 & $\mathrm{C}_{15} \mathrm{H}_{20} \mathrm{O}$ & Others \\
\hline $\begin{array}{l}\text { Pyrrolo[1,2-a]pyrazine-1,4-dione, } \\
\text { hexahydro-3-(2-methylpropyl)- }\end{array}$ & 11.932 & 0.84 & 210 & $\mathrm{C}_{11} \mathrm{H}_{18} \mathrm{~N}_{2} \mathrm{O}_{2}$ & Alkaloids \\
\hline $\begin{array}{l}\text { 9,12,15-Octadecatrienoic acid, methyl ester, } \\
(\mathrm{Z}, \mathrm{Z}, \mathrm{Z})-\end{array}$ & 12.534 & 0.38 & 292 & $\mathrm{C}_{19} \mathrm{H}_{32} \mathrm{O}_{2}$ & Fatty acid \\
\hline Phytol & 12.583 & 1.31 & 296 & $\mathrm{C}_{20} \mathrm{H}_{40} \mathrm{O}$ & Terpenoids \\
\hline$\gamma$-tocopherol & 15.587 & 2.38 & 416 & $\mathrm{C}_{28} \mathrm{H}_{48} \mathrm{O}_{2}$ & Phenol \\
\hline n-Tetracosanol-1 & 15.699 & 1.56 & 354 & $\mathrm{C}_{24} \mathrm{H}_{50} \mathrm{O}$ & Fatty acid \\
\hline Vitamin E & 15.888 & 0.52 & 430 & $\mathrm{C}_{29} \mathrm{H}_{50} \mathrm{O}_{2}$ & Vitamin $\mathrm{E}$ \\
\hline 1-Heptacosanol & 16.553 & 0.91 & 396 & $\mathrm{C}_{27} \mathrm{H}_{56} \mathrm{O}$ & Fatty acid \\
\hline$\gamma$-sitosterol & 16.791 & 2.98 & 414 & $\mathrm{C}_{29} \mathrm{H}_{50} \mathrm{O}$ & Sterols \\
\hline
\end{tabular}

Table 5. $I C_{50}$ Values of Cytotoxic Activity from Pereskia bleo Leaf Crude Solvent Extracts Against Cancer (HeLa, MDA-MB-231, and SW480) and NIH/3T3 Normal Cell Lines

\begin{tabular}{lcccc}
\hline \multirow{2}{*}{$\begin{array}{l}\text { Extract } \\
\text { solvents }\end{array}$} & \multicolumn{4}{c}{$\mathrm{IC}_{50}$ values $\left(\mu \mathrm{g} \mathrm{mL}^{-1}\right)$} \\
\cline { 2 - 5 } Hexane & HeLa & MDA-MB-231 & $\mathrm{SW} 480$ & $\mathrm{NIH} / 3 \mathrm{~T} 3$ \\
Ethyl acetate & $17.51 \pm 12.8$ & $95.75 \pm 27.9$ & $154.0 \pm 2.0$ & $275.0 \pm 16.0$ \\
Methanol & $683.47 \pm 15.7$ & $19.39 \pm 1.26$ & $31.80 \pm 16.1$ & $182.0 \pm 23.0$ \\
Aqueous & $100.40 \pm 2.3$ & $213.23 \pm 27.7$ & $>990$ & $631.0 \pm 22.0$ \\
Tamoxifen & $2.71 \pm 0.88$ & $2.24 \pm 0.95$ & $128.2 \pm 7.5$ & $359.5 \pm 27.5$ \\
\hline
\end{tabular}

GCMS investigation of crude hexane extract of $P$. bleo leaves showed the presence of terpenoids, sterols and phenolic compounds. Sterols were the highest in the hexane extract comprising of $\gamma$-sitosterol (17.53\%) as the main compound followed by phenolic compounds. Earlier literatures recorded phenolic compounds and $\beta$-sitosterol from the hexane fraction. ${ }^{[5,17]} \gamma$-sitosterol has been previously reported to influence cholesterol synthesis in liver and intestinal cell lines. ${ }^{[18]}$ It also acts as a cytotoxic sensitizing agent. ${ }^{[19]}$ In addition, $\gamma$ sitosterol from Strobilanthes crispus leaves extract was cytotoxic against colon and liver cancer cell lines. ${ }^{[20]}$ Additionally, $\beta$-tocopherol and $\gamma$-tocopherol identified in this extract, are well known for their antioxidant properties. ${ }^{[21]}$ Recent studies also have reviewed the benefits of these compounds such as anticancer, anti-inflammatory, and cancer preventive effects. ${ }^{[22,23]}$

Phytol was the major compound isolated from the ethyl acetate extract of P. bleo leaves. The results showed that the ethyl acetate extract exerted the most potent cytotoxic effect against HeLa cells followed by MDA-MB-231 cells. 
According to the National Cancer Institute (NCI), a plant crude extracts should have an $\mathrm{IC}_{50}$ of less than $20 \mu \mathrm{g} \mathrm{mL}{ }^{-1}$ for potent cytotoxic effect. ${ }^{[24]}$ Similar findings were reported by previous studies where this extract was cytotoxic against human nasopharynx cancer (KB) cell lines. ${ }^{[6,25]}$ Phytol is believed to have anticancer properties, ${ }^{[26]}$ triggering apoptosis in liver and lung cancer cells activated via caspase 3 and 9 pathway. ${ }^{[27,28]}$ Besides phytol, other prominent compounds such as loliolide, neophytadiene and $\gamma$ - sitosterol were found in this study. Loliolide has been reported for its antioxidant ${ }^{[29]}$ and antiproliferative effects. ${ }^{[30]}$ Meanwhile neophytadiene was widely known for its antioxidant properties. ${ }^{[31]}$ The cytotoxic effect of this extract toward different cancer cell lines maybe due to the synergistic effect of all the compounds.

The methanol extracts also had terpenoids, sterols, alkaloids, phenols, and fatty acids and did not exert cytotoxic effects in the tested cell lines, which is contrary to previous reports of cytotoxicity against breast cancer (T47-D) cell lines. ${ }^{[10]}$ This may be because the phytochemicals are selectively sensitive toward different cell lines.

Sim et al. ${ }^{[17]}$ reported the presence of phenolic compound in the aqueous extract of $P$. bleo leaves which only measured total phenolic content while the present study has elucidated single compounds from the phenolic group namely 2-methoxy-4-vinylphenol and $\gamma$-tocopherol. Sharif et al. ${ }^{[16]}$ reported that aqueous extract of $P$. bleo leaves contained fatty acids and high content of myo-inositol and sugars (galactose and phenanthrene). On the contrary, GCMS analysis in this study revealed the presence of alkaloids, terpenoids, fatty acids and phenolic compounds. Phenol was the major compound identified in the aqueous extract of $P$. bleo leaves. These differences might be due to the different temperature used during extraction. Sharif et al. ${ }^{[16]}$ carried out extraction at $30^{\circ} \mathrm{C}$ while the temperature used in this study was $50^{\circ} \mathrm{C}$. Extraction at a higher temperature releases higher phenolic compound compared to lower temperature. ${ }^{[32]}$

The present study showed that the ethyl acetate extract of $P$. bleo leaves had the highest cytotoxic effect toward HeLa and MDA-MB-231 cell lines. Potent biological effects of this plant extract are associated with the phytochemical compounds present in the plant. Further analysis is required to investigate the mechanism of cancer cell death induced by this plant.

\section{Acknowledgments}

The authors would like to thank Universiti Sains Malaysia for providing financial support under the Short Term Grant Scheme (304/PPSP/6315179).

\section{Funding}

This work was supported by the Universiti Sains Malaysia [Short Term Grant (304/PPSP/ 6315179)]. 


\section{Conflict of interest statement}

None to be declared by all authors.

\section{ORCID}

Siti Farhanah Mohd-Salleh (1) http://orcid.org/0000-0002-3048-702X

\section{References}

[1] Kooti, W.; Servatyari, K.; Behzadifar, M.; Asadi-Samani, M.; Sadeghi, F.; Nouri, B.; Zare Marzouni, H.; et al. Effective Medicinal Plant in Cancer Treatment, Part 2: review Study. J. Evid. Based Complementary Altern. Med. 2017, 22(4), 982-995.

[2] Zaid, H.; Silbermann, M.; Amash, A.; Gincel, D.; Abdel-Sattar, E.; et al. Medicinal Plants and Natural Active Compounds for Cancer Chemoprevention/Chemotherapy. Evid. Based Complement. Alternat. Med. 2017, 2017, 1-2. DOI: 10.1155/2017/ 7952417.

[3] Kuruppu, A. I.; Paranagama, P.; Goonasekara, C. Medicinal Plants Commonly Used against Cancer in Traditional Medicine Formulae in Sri Lanka. Saudi Pharm. J. 2019, 27(4), 565-573. DOI: 10.1016/j.jsps.2019.02.004.

[4] Wahab, S.; Abdul, A.; Mohan, S.; Al-Zubain, A.; Elhassan, M.; Ibrahim, M. Biological Activities of Pereskia beo Extracts. Int. J. Pharmacol. 2009, 5(1), 71-75. DOI: 10.3923/ ijp.2009.71.75.

[5] Abdul-Wahab, I. R.; Guilhon, C. C.; Fernandes, P. D.; Boylan, F. Anti-nociceptive Activity of Pereskia Bleo Kunth. (Cactaceae) Leaves Extracts. J. Ethnopharmacol. 2012, 144(3), 741-746.

[6] Malek, S. N. A.; Shin, S. K.; Wahab, N. A.; Yaacob, H. Cytotoxic Components of Pereskia Bleo (Kunth) DC. (Cactaceae) Leaves. Molecules 2009, 14(5), 1713-1724. DOI: 10.3390/molecules14051713.

[7] Yen, K. P.; Abdullah, M. S. B.; Syafri, S.; Raju, S. K.; Yahya, C. A Preliminary Survey on the Medicinal Uses and Effectiveness of Pereskia Bleo Used by People of Three Villages in the State of Kelantan, Malaysia. Int. J. Herb. Med. 2013, 1(3), 1-4.

[8] Rasoanaivo, P.; Wright, C. W.; Willcox, M. L.; Gilbert, B. Whole Plant Extracts versus Single Compounds for the Treatment of Malaria: Synergy and Positive Interactions. Malar. J. 2011, 10(1), S4. DOI: 10.1186/1475-2875-10-S1-S4.

[9] Er, H. M.; Cheng, E. H.; Radhakrishnan, A. K. Anti-proliferative and Mutagenic Activities of Aqueous and Methanol Extracts of Leaves from Pereskia Bleo (Kunth) DC (Cactaceae). J. Ethnopharmacol. 2007, 113(3), 448-456. DOI: 10.1016/j. jep.2007.06.026.

[10] Tan, M. L.; Sulaiman, S. F.; Najimuddin, N.; Samian, M. R.; Muhammad, T. S. Methanolic Extract of Pereskia Bleo (Kunth) DC. (Cactaceae) Induces Apoptosis in Breast Carcinoma, T47-D Cell Line. J. Ethnopharmacol. 2005, 96(1-2), 287-294. DOI: 10.1016/j.jep.2004.09.025.

[11] Zhang, Q. W.; Lin, L. G.; Ye, W. C. Techniques for Extraction and Isolation of Natural Products: a Comprehensive Review. Chin. Med. 2018, 13(1), 1-26. DOI: 10.1186/ s13020-018-0177-x.

[12] Handa, S. S.; Khanuja, S. P. S.; Longo, G.; Rakesh, D. D. Extraction Technologies for Medicinal and Aromatic Plants (United Nations Industrial Development Organisation 
and the International Centre for Science and High Technology). Int. Centre Sci. and High Tech. UN Ind. Dev. Org., area Sci. Park Padriciano. 2008, 99, 34012.

[13] Wu, C.; Wang, F.; Liu, J.; Zou, Y.; Chen, X. A Comparison of Volatile Fractions Obtained from Lonicera Macranthoides via Different Extraction Processes: ultrasound, Microwave, Soxhlet Extraction, Hydrodistillation, and Cold Maceration. Integr. Med. Res. 2015, 4(3), 171-177. DOI: 10.1016/j.imr.2015.06.001.

[14] Deslauriers, I. Recovery, Separation and Characterization of Phenolic Compounds and Flavonoids from Maple Products, McGill University Canada. 2002.

[15] Wang, Y.; Liu, S.; Hu, Y.; Li, P.; Wan, J. B. Current State of the Art of Mass Spectrometry-based Metabolomics Studies-a Review Focusing on Wide Coverage, High Throughput and Easy Identification. RSC Adv. 2015, 5(96), 78728-78737. DOI: 10.1039/C5RA14058G.

[16] Sharif, K. M.; Rahman, M. M.; Azmir, J.; Shamsudin, S. H.; Uddin,; Uddin, M. S.; Fahim, T. K.; Zaidul, I. S. M.; et al. Ethanol Modified Supercritical Carbon Dioxide Extraction of Antioxidant Rich Extract from Pereskia Bleo. J. Ind. Eng. Chem. 2015, 21, 1314-1322. DOI: 10.1016/j.jiec.2014.05.047.

[17] Sim, K. S.; Sri Nurestri, A. M.; Norhanom, A. W. Phenolic Content and Antioxidant Activity of Crude and Fractionated Extracts of Pereskia Bleo (Kunth) DC. (Cactaceae). Afr. J. Pharm. Pharmacol. 2010, 4(5), 193-201.

[18] Ho, S. S.; Pal, S. Margarine Phytosterols Decrease the Secretion of Atherogenic Lipoproteins from HepG2 Liver and Caco2 Intestinal Cells. Atherosclerosis 2005, 182 (1), 29-36. DOI: 10.1016/j.atherosclerosis.2005.01.031.

[19] Carter, B. A.; Taylor, O. A.; Prendergast, D. R.; Zimmerman, T. L.; Furstenberg, V.; Moore, D. D.; Karpen, S. J.; et al. Stigmasterol, a Soy Lipid-derived Phytosterol, Is an Antagonist of the Bile Acid Nuclear Receptor FXR. Pediatr. R. 2007, 62(3), 301-306. DOI:10.1203/PDR.0b013e3181256492.

[20] Endrini, S.; Rahmat, A.; Ismail, P.; Taufiq-Yap, Y. H. Cytotoxic Effect of $\gamma$-sitosterol from Kejibeling (Strobilanthes Crispus) and Its Mechanism of Action Towards C-myc Gene Expression and Apoptotic Pathway. Med. J. Indones. 2015, 23(4), 203-208. DOI: 10.13181/mji.v23i4.1085.

[21] Nielsen, M. M. L.; Hansen, Å. Rapid High-Performance Liquid Chromatography Determination of Tocopherols and Tocotrienols in Cereals. Cereal Chem. 2008, 85(2), 248-251. DOI: 10.1094/CCHEM-85-2-0248.

[22] Cervinkova, B.; Krcmova, L. K.; Solichova, D.; Melichar, B.; Solich, P. Recent Advances in the Determination of Tocopherols in Biological Fluids: from Sample Pretreatment and Liquid Chromatography to Clinical Studies. Anal. Bioanal. Chem. 2016, 408(10), 2407-2424. DOI: 10.1007/s00216-015-9214-0.

[23] Constantinou, C.; Charalambous, C.; Kanakis, D. Vitamin E and Cancer: an Update on the Emerging Role of Gamma and Delta Tocotrienols. Eur. J. Nutr. 2019, 1-13.

[24] Srisawat, T.; Chumkaew, P.; Heed-Chim, W.; Sukpondma, Y.; Kanokwiroon, K. Phytochemical Screening and Cytotoxicity of Crude Extracts of Vatica Diospyroides Symington Type LS. Trop. J. Pharm. Res. 2013, 12(1), 71-76.

[25] Sri, N.; Norhanom, A. W.; Hashim, Y.; Shin, S.; Lai, H.; et al. Cytotoxic Activity of Pereskia Bleo (Cactaceae) against Selected Human Cell Lines. Int. J. Canc. Res. 2010, 6 (3), 180-187.

[26] Jeong, S. H.;. Inhibitory Effect of Phytol on Cellular Senescence. Biomed. Dermatol. 2018, 2(13), 1-9. DOI: 10.1186/s41702-018-0025-8.

[27] Kim, C. W.; Lee, H. J.; Jung, J. H.; Kim, Y. H.; Jung; et al. Activation of Caspase-9/3 and Inhibition of Epithelial Mesenchymal Transition are Critically Involved in Antitumor 
Effect of Phytol in Hepatocellular Carcinoma Cells. Phytother Res. 2015, 29(7), 1026-1031.

[28] Thakor, P.; Subramanian, R. B.; Thakkar, S. S.; Ray, A.; Thakkar, V. R. Phytol Induces ROS Mediated Apoptosis by Induction of Caspase 9 and 3 through Activation of TRAIL, FAS and TNF Receptors and Inhibits Tumor Progression Factor Glucose 6 Phosphate Dehydrogenase in Lung Carcinoma Cell Line (A549). Biomed. Pharmacother. 2017, 92, 491-500. DOI: 10.1016/j.biopha.2017.05.066.

[29] Yang, X.; Kang, M. C.; Lee, K. W.; Kang, S. M.; Lee, W. W.; Jeon, Y. J. Antioxidant Activity and Cell Protective Effect of Loliolide Isolated from Sargassum Ringgoldianum Subsp. Coreanum. Algae 2011, 26(2), 201-208. DOI: 10.4490/algae.2011.26.2.201.

[30] Machado, F. B.; Yamamoto, R. E.; Zanoli, K.; Nocchi, S. R.; Novello,; Novello, C. R.; Schuquel, I. T. A.; Sakuragui, C. M.; Luftmann, H.; Ueda-Nakamura, T.; et al. Evaluation of the Antiproliferative Activity of the Leaves from Arctium Lappa by a Bioassay-guided Fractionation. Molecules 2012, 17(2), 1852-1859.

[31] Yamuna, P.; Abirami, P.; Vijayashalini, P.; Sharmila, M. GC-MS Analysis of Bioactive Compounds in the Entire Plant Parts of Ethanolic Extract of Gomphrena Decumbens Jacq. J. Med. Plants. 2017, 5(3), 31-37.

[32] Prenesti, E.; Berto, S.; Daniele, P. G.; Toso, S. Antioxidant Power Quantification of Decoction and Cold Infusions of Hibiscus Sabdariffa Flowers. Food Chem. 2007, 100 (2), 433-438. DOI: 10.1016/j.foodchem.2005.09.063. 